\title{
Environmental Factors and Seasonal Variation in Density of Mussel Larvae (Mytilus edulis) in Danish Waters
}

\author{
Hans Ulrik Riisgård1*, Kim Lundgreen ${ }^{1}$, Daniel Pleissner² \\ ${ }^{1}$ Marine Biological Research Centre, University of Southern Denmark, Kerteminde, Denmark \\ ${ }^{2}$ Department of Bioengineering, Leibniz-Institute for Agricultural Engineering Potsdam-Bornim e. V., Potsdam, \\ Germany \\ Email: ${ }^{*}$ hur@biology.sdu.dk
}

Received 29 May 2015; accepted 13 July 2015; published 16 July 2015

Copyright (C) 2015 by authors and Scientific Research Publishing Inc.

This work is licensed under the Creative Commons Attribution International License (CC BY). http://creativecommons.org/licenses/by/4.0/

(c) (i) Open Access

\section{Abstract}

Mussel larval densities may fluctuate considerably on both small spatial and short temporal scales. So far, only few and scattered data on the occurrence of mussel larvae have been reported from Danish waters. However, seasonal variation in density of blue mussel (Mytilus edulis) larvae as related to environmental factors (temperature, salinity, phytoplankton biomass) is basic information of relevance for future line-mussel farming in Danish waters. Here we report on the density of mussel larvae in a number of potential farming sites in the inner Danish waters. The mussel larval density measured in Skive Fjord, an eutrophicated inner branch of Limfjorden, during a period of 20 years, from 1989 to 2009, along with corresponding temperatures and chlorophyll $a$, makes up the most important series of data reported here. In most years, a pronounced spring density peak and a subsequently lower autumn peak could be seen in Skive Fjord, but most conspicuous in the period 1993 to 2002 where the mean maximum spring larval density was $319 \pm 260$ ind·1-1. Further, data on mussel larval densities have been recorded on 4 locations in the Great Belt region: Kerteminde Bay in 2008 to 2011, and in 2008 at 3 other locations: Musholm Bay, Svendborg Sund, and Horsens Fjord. The maximum spring densities in the studied waters were observed in Skive Fjord, typically in May, whereas 10 to 100 times lower peak densities were found at the other locations studied. The reported observations show that mussel larvae are omnipresent in the studied areas and it is suggested that the larval density is sufficient for recruitment to future linemussel farms.

\section{Keywords}

Mussel Larval Density, Seasonal Variation, Environmental Factors, Mytilus edulis

\footnotetext{
${ }^{*}$ Corresponding author.
}

How to cite this paper: Riisgård, H.U., Lundgreen, K. and Pleissner, D. (2015) Environmental Factors and Seasonal Variation in Density of Mussel Larvae (Mytilus edulis) in Danish Waters. Open Journal of Marine Science, 5, 280-289. 


\section{Introduction}

The common blue mussel, Mytilus edulis L. may reproduce at any time of the year, but in the temperate zone spawning is most frequent during spring and summer [1]. Temperature seems to be the most important factor that determines the annual reproductive cycle, and a cold winter tends to synchronize spawning the following spring [2]-[4]. The fertilized egg develops within $24 \mathrm{~h}$ to a trochophora larva that soon after secrets the first larval shell to become a free swimming D-shaped veliger larva (100 to $120 \mu \mathrm{m}$ shell length) feeding on small 2 to $4 \mu \mathrm{m}$ particles [5]-[9]. This stage lasts between 3 and 5 weeks [10], i.e. time to reach $\sim 300 \mu \mathrm{m}$, depending on environmental factors (temperature, food ration, salinity) until metamorphosis when an extensible foot appears and the larva becomes a pediveliger. The pediveliger larva seeks out different types of substrates in preparation for settlement which involves a sequence of swimming and crawling behavior that culminates in attachment once a suitable substrate is chosen. After settlement, morphological change (metamorphosis) results in a young post-metamorphic mussel [5] [9]. It is well known that mussel larval densities may fluctuate considerably on both relatively small spatial (tens of metres) and short temporal scales (days) depending on the hydrography [11], but although information on density and dispersal of mussel larvae is crucial for understanding recruitment to the adult wild stock and to aquaculture farm-ropes, only few and scattered data have up to now been reported from Danish waters.

The Danish mussel production mainly comes from fishery on wild stocks of blue mussels in Limfjorden which is a shallow-water system that connects with the North Sea to the west and Kattegat to the east (Figure 1). The annual landings of blue mussels were about 100,000 tons in the 1990's resulting in overfishing and a subsequent reduction of the mussel stock, and in 2006-2008 the mussel fishery declined to about 30,000 tons per year which led to restrictions and a national policy that aims at developing a sustainable production of cultured mussels in balance with the extensive fishery of mussels [12]-[14]. In recent years, the total annual Danish mussel harvest has been around 35,000 tons, with 70\% coming from Limfjorden. However, eutrophication and seasonal oxygen depletion in Limfjorden cause high mortality of bottom-living wild mussels during late summer [15], and therefore, line-mussel farming has recently been introduced to increase the production of mussels and to mitigate the habitat disturbance of mussel dredging [16].

The aim of a recent mussel-research project (MarBioShell, 2008-2012) was to evaluate the potential of the Great Belt region between the Kattegat and the Baltic Sea (Figure 1) as a new line-mussel cultivation site to reduce the pressure on Limfjorden. Based on studies of actual growth of mussels in net-bags and on farm-ropes, Riisgård et al. [16] found that the growth rates in Great Belt compare quite well with the growth in Limfjorden in spite of the lower salinity in Great Belt [17]-[19], and further, the deeper water and faster current speeds in Great Belt are likely to prevent the eutrophication problems encountered in Limfjorden. The wild blue mussels in the Great Belt have never been commercially exploited, but the MarBioShell studies showed that line-mussels can grow from settlement in spring to more than $30 \mathrm{~mm}$ in shell length in November [17]. However, to reach the traditional consumer size of at least $45 \mathrm{~mm}$ takes about 18 months because of the winter period with weight loss and subsequent re-growth during the next season, and therefore, Riisgård et al. [17] suggested a new approach of line farming of $30 \mathrm{~mm}$ "mini-mussels" during one growth season.

On this background, knowledge on seasonal variation in density of mussel larvae in Great Belt has become important. Limfjorden and Great Belt have different levels of phytoplankton biomass (chlorophyll $a$ ), salinity and current regimes, and therefore it has been of interest to compare the seasonal variation in density of mussel larvae in Limfjorden with the abundance of mussel larvae in Great Belt and nearby waters as done in the present study, where a 20 years long time series of mussel-larval data from Limfjorden is compared with new observations made on 4 locations in the Great Belt region. Such knowledge is of basic importance for understanding time of mussel-larval settlement and amount of new recruitment to future mussel farms.

\section{Material and Methods}

\subsection{Study Sites in Limfjorden and the Great Belt Region}

Limfjorden connects the North Sea with the Kattegat, the mean water depth is about $5 \mathrm{~m}$, and dominating westerly winds cause a water exchange between the North Sea in west and Kattegat in the east (Figure 1), and there is a permanent horizontal salinity gradient, with 32 to 34 psu in the west and 19 to 25 psu in the east. Limfjorden 


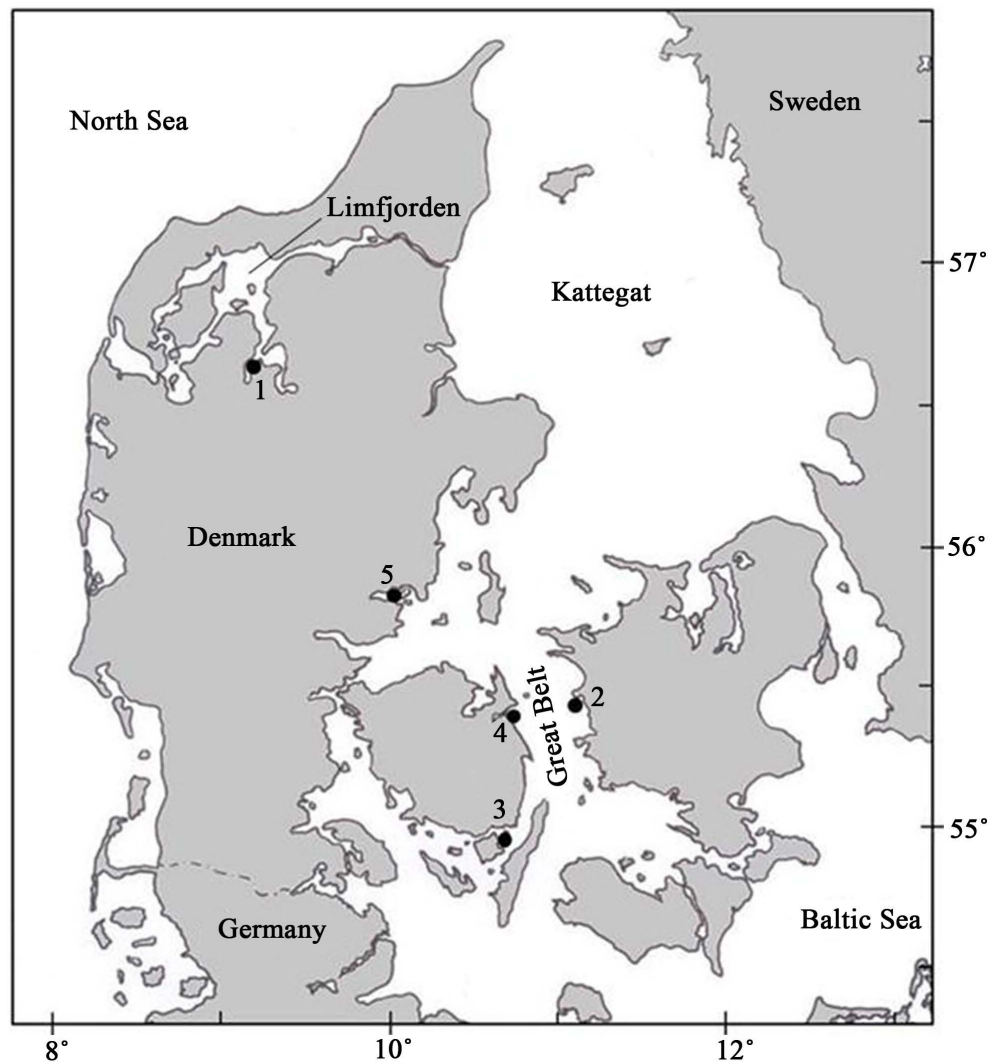

Figure 1. Map of Denmark showing Mytilus edulis larval sampling sites in Limfjorden: (1) Skive Fjord, and in the Great Belt region: (2) Musholm Bay, (3) Svendborg Sund, (4) Kerteminde Bay, (5) Horsens Fjord.

is eutrophic receiving nutrients from the catchment area which is dominated by agriculture [15]. The water current velocity $1 \mathrm{~m}$ above the bottom varies typically between $<1$ to $6 \mathrm{~cm} \cdot \mathrm{s}^{-1}$, and the annual mean chlorophyll $a$ concentration in the period 1982 to 2006 in the central northern part of Limfjorden (Løgstør Bredning) was $7.5 \pm$ $12.1 \mu \mathrm{g} \cdot \mathrm{l}^{-1}[18]$.

Data on mussel larval density in Skive Fjord, which is an inner branch of Limfjorden (Figure 1), during the period 1989 to 2009 were obtained from the Danish national monitoring program, Danish Nature Agency, Danish Ministry of Environment. According to the official monitoring guidelines (Miljøcenter Ringkøbing 2008), 20 l of water were sampled by means of a submersible pump $\left(150 \mathrm{l} \cdot \mathrm{min}^{-1}\right)$ resulting in equally sized subsamples taken through the water column from bottom to surface by hauling the pump up with a speed of $0.5 \mathrm{~m} \cdot \mathrm{s}^{-1}$. The sampled water was filtered (60 $\mu \mathrm{m}$ mesh) to obtain a representative sample of the mussel larvae. Samples were preserved in basic Lugol's solution and examined in the laboratory by Orbicon A/S in order to determine the concentration of mussel veliger larvae (and other zooplankton organisms).

Great Belt is one of the 3 Danish Straits (i.e. Little Belt, Great Belt, and The Sound), which form the transition between the high saline North Sea and the brackish Baltic Sea (Figure 1). The water exchange between the Baltic Sea and the open sea is driven both by the river run-off and by the meteorological conditions. The surface salinity in the Great Belt is low, less than 20 psu whereas the salinity beneath the permanent halocline at about $15 \mathrm{~m}$ depth is high, about 30 to $34 \mathrm{psu}$. The current speed is usually about $50 \mathrm{~cm} \cdot \mathrm{s}^{-1}$, and the annual mean chlorophyll $a$ concentration measured in the period 2000 to 2010 at $1 \mathrm{~m}$ depth in the northern Great Belt was $2.8 \pm$ $2.4 \mu \mathrm{g} \cdot l^{-1}[17]-[19]$.

The present study reports on mussel larval density in the Great Belt region, including Horsens Fjord (Figure 1), during the period 2008 to 2011. Water samples were collected at the 4 locations in 2008: Musholm Bay, Svendborg Sund, Kerteminde Bay, and Horsens Fjord, and further in Kerteminde Bay in the period 2009 to 2011 by using a small conical zooplankton net (Ø24 cm, KC Denmark) with a mesh size of $80 \mu \mathrm{m}$ and a $80 \mathrm{ml}$ 
collection cylinder. The plankton net was dropped to a known depth and then slowly hauled to the surface. The sample was then transferred to a $100 \mathrm{ml}$ bottle containing Lugol to conserve the mussel larvae. Before counting in the laboratory using a reversed microscope (Leitz Labovert FS), the sample bottle was turned upside down several times to ensure an even distribution of the mussel larvae. The total number of counted larvae was expressed as individuals per liter of filtrated water. The filtrated water volume $(V)$ was calculated from the circular area of the plankton net $\left(A=0.045 \mathrm{~m}^{2}\right)$ and the length $(L)$ of the vertical haul through the water column $(V=A \times$ $L$ ) which was dependent on the depth at the sampling location (2 to $6 \mathrm{~m}$ ).

\subsection{Environmental Data}

Data on chlorophyll $a$, salinity and temperature in the Great Belt region and Skive Fjord were obtained from the Danish national monitoring program, Danish Nature Agency, Danish Ministry of Environment. Temperature and salinity were measured with a CTD at heights spaced $0.2 \mathrm{~m}$ apart, from $0.8 \mathrm{~m}$ below the surface down to about $0.3 \mathrm{~m}$ above the bottom. Chlorophyll $a$ (chla) was determined from water samples taken from a depth of $1 \mathrm{~m}$ and subsequently analysed at an authorized laboratory according to Danish national standards.

\subsection{Statistical Analysis}

One-way repeated measures analysis of variance (ANOVA) and Pearson product moment correlation (SigmaPlot, version 12) were used to evaluate seasonal larval densities and temperature data, respectively. In all cases a significance level of $\alpha=0.05$ was used.

\section{Results}

\subsection{Larval Densities in Limfjorden and Great Belt Region}

\subsubsection{Limfjorden}

The mussel larval density measured in Skive Fjord during a period of 20 years, from January 1989 to January 2009, along with corresponding temperatures and phytoplankton biomass expressed as chlorophyll $a$ are shown in Figure 2 and Figure 3. In most years, a pronounced spring density peak and a subsequently lower autumn
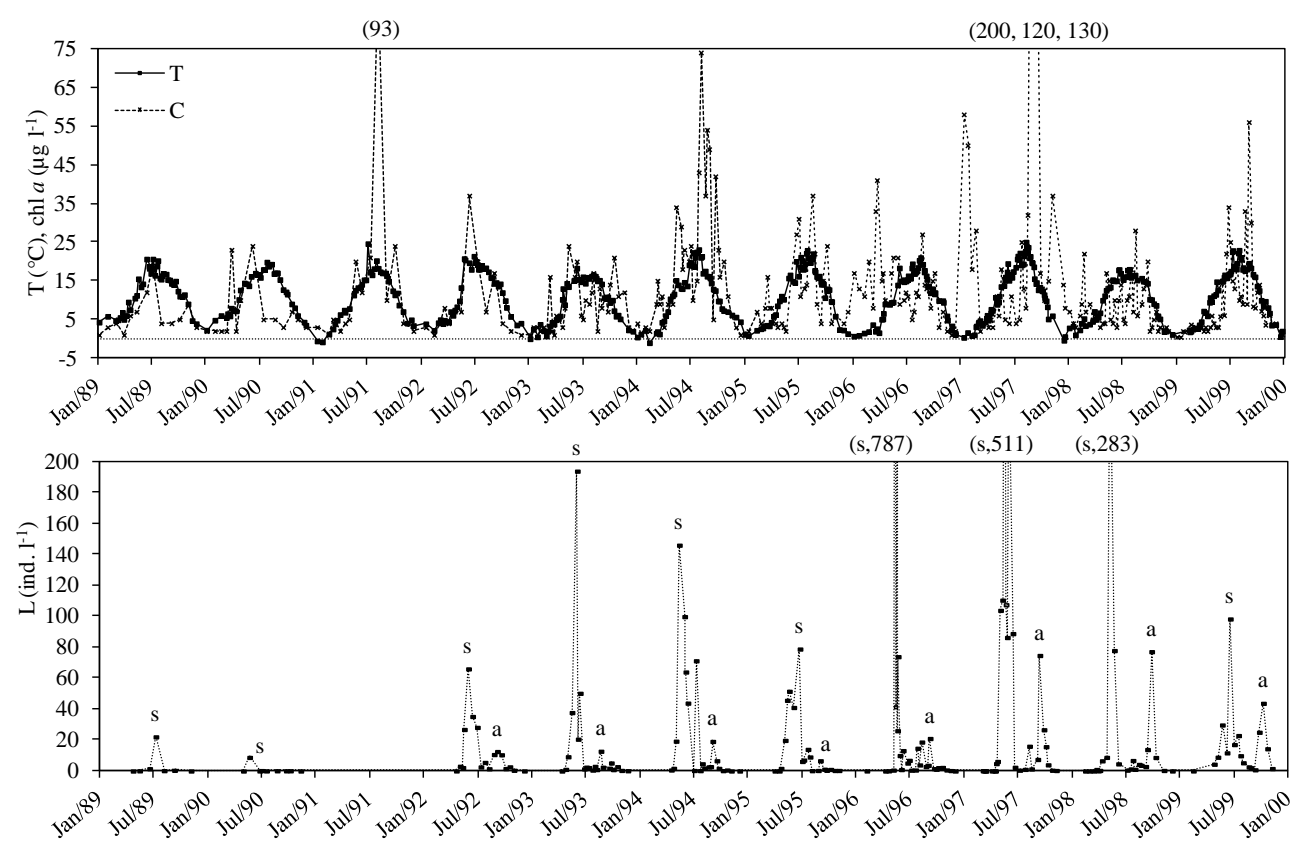

Figure 2. Mytilus edulis. Temperature $\left(\mathrm{T},{ }^{\circ} \mathrm{C}\right)$, chlorophyll $a\left(\mathrm{C}, \mu \mathrm{g} \cdot \mathrm{l}^{-1}\right)$ (upper graph) and mussel larval density (L, ind $\cdot \mathrm{l}^{-1}$ ) (lower graph) in Skive Fjord in the period 1989 to 1999. Spring (s) and autumn (a) peaks are indicated. Values exceeding $75 \mu \mathrm{g}$ chla $\cdot \mathrm{l}^{-1}$ and $200 \mathrm{ind} \cdot \mathrm{l}^{-1}$ are shown in brackets. Mean \pm S.D. salinity in the period was $24.3 \pm 2.0$ psu. 

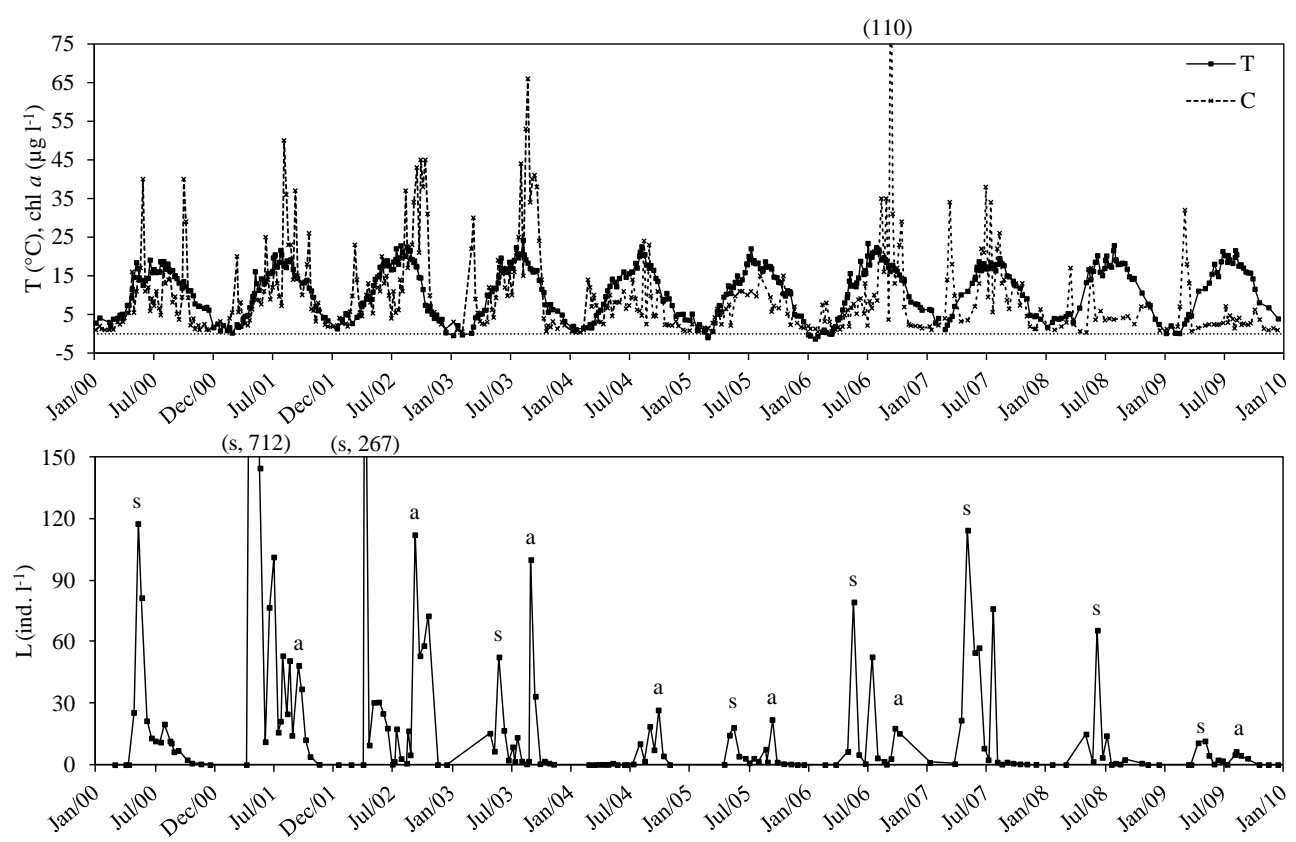

Figure 3. Mytilus edulis. Temperature $\left(\mathrm{T},{ }^{\circ} \mathrm{C}\right)$, chlorophyll $a\left(\mathrm{C}, \mu \mathrm{g} \cdot \mathrm{l}^{-1}\right)$ (upper graph) and mussel larval density (L, ind $\cdot \mathrm{l}^{-1}$ ) (lower graph) in Skive Fjord in the period 2000 to 2009. Spring (s) and autumn (a) peaks are indicated. Values exceeding $75 \mu \mathrm{g} \mathrm{chla} \cdot \mathrm{l}^{-1}$ and $150 \mathrm{ind} \cdot \mathrm{l}^{-1}$ are shown in brackets. Mean \pm S.D. salinity in the period was $23.1 \pm 2.1$ psu.

peak can be seen. This trend, however, seems to be most conspicuous in the period 1993 to 2002 (with mean maximum larval densities of $319.1 \pm 260.0$ ind $\cdot \mathrm{l}^{-1}$ ), and therefore the mean maximum spring and mean autumn mussel larval densities for this period have been compared to previous (1989 to 1992, with $32.0 \pm 30.3$ ind $\cdot \mathrm{l}^{-1}$ ) and subsequent (2003 to 2009, $56.7 \pm 38.6$ ind $\cdot l^{-1}$ ) periods in Table 1 . The few scattered data for the period 1989 to 1992 are not adequate for statistical tests, but statistical analysis showed that the spring density of mussel larvae in the period 1993 to 2002 was significantly different $(P<0.05)$ from the subsequent period 2003 to $2009\left(F_{(1,15)}=7.528, P=0.041\right)$. However, the difference in autumn larval density in the same two periods (46.2 \pm 35.6 versus $37.5 \pm 35.8$ ind $\left.\cdot l^{-1}\right)$ was not significantly different $\left(F_{(1,15)}=0.00249, P=0.962\right)$. The mean annual temperatures in Skive Fjord from 1982 to 2009 (Figure 4) varied between 9.5 to $13^{\circ} \mathrm{C}$, and a statistical test showed that there has been no significant increase in the mean annual temperatures $(P=0.452)$.

\subsubsection{Great Belt}

The densities of mussel larvae recorded in Kerteminde Bay in the period 2008 to 2011 are shown in Figure 5, and the date of maximum spring density of 3.4 to 7.9 ind $\cdot l^{-1}$ appears from Table 2. The larval density recorded in Musholm Bay, Svendborg Sund and Horsens Fjord in 2008 are shown in Figure 6 along with salinity, temperature and chlorophyll $a$, and mean values of the latter in the sampling period are shown in Table 3. It is seen that the maximum spring densities vary between 2.7 (Musholm Bay) and 12.4 larvae $\mathrm{l}^{-1}$ (Svendborg Sund). There is no statistical difference ( $P=0.586, H=1.936$ with 3 degrees of freedom) in mussel larval density between the 4 locations in the Great Belt region. However, due the limited number of measurements of larval density in Kerteminde Bay, only the period between July and October 2008 could be investigated for all locations.

\section{Discussion}

A pronounced spring peak in mussel larval density is typical for all locations studied, and the maximum spring densities are found in Limfjorden (Figure 2 and Figure 3, Table 1 and Table 4) whereas much lower peak densities are found at the 4 locations in the Great Belt region. (Figure 5 and Figure 6, Table 2 and Table 3). The first yearly occurrence of mussel larvae, typically between mid-May and early June, appears to be closely related to the annual temperature cycle which apparently synchronize the spring spawning which seems to take place when the water temperature has increased to about $12^{\circ} \mathrm{C}$, as reflected in the subsequent first appearance of 


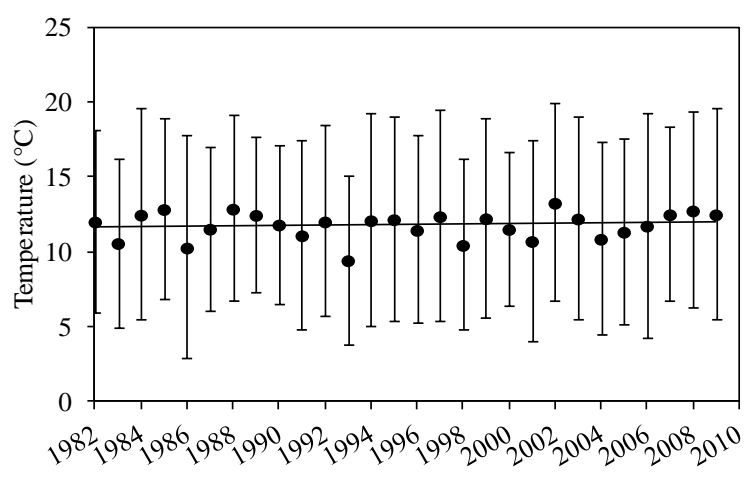

Figure 4. Annual mean ( \pm S.D.) temperatures in Skive Fjord in the period 1982 to 2009.

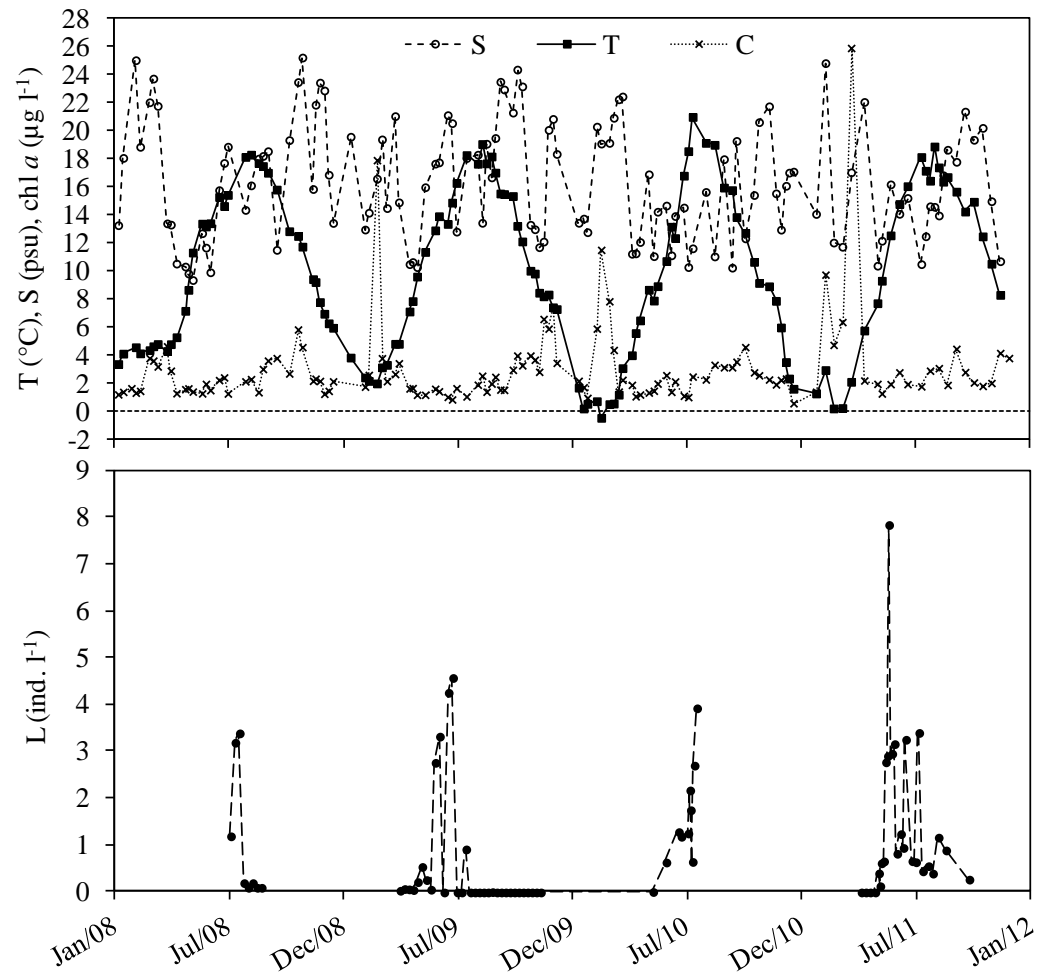

Figure 5. Mytilus edulis. Salinity (S, psu), temperature $\left(\mathrm{T},{ }^{\circ} \mathrm{C}\right)$, chla $\left(\mathrm{C}, \mu \mathrm{g} \cdot \mathrm{l}^{-1}\right)$, and mussel larval density (L, ind $\cdot l^{-1}$ ) in Kerteminde Bay in 2008 to 2011.

Table 1. Mytilus edulis. Mean \pm S.D. maximum larval densities in Skive Fjord in spring and autumn in 3 periods between 1989 and 2009 along with corresponding water temperature, salinity and chlorophyll $a$.

\begin{tabular}{cccccc}
\hline Years & Season & Max. density $\left(\right.$ ind $\left.\cdot l^{-1}\right)$ & Temp. $\left({ }^{\circ} \mathrm{C}\right)$ & Salinity (psu) & Chla $\left(\mu \mathrm{g} \cdot l^{-1}\right)$ \\
\hline $1989-1992$ & Spring & $32.0 \pm 30.3$ & $18.4 \pm 3.6$ & $23.0 \pm 2.6$ & $19.3 \pm 2.5$ \\
$1993-2002$ & Spring & $319.1 \pm 260.0$ & $13.8 \pm 3.9$ & $22.0 \pm 1.8$ & $17.9 \pm 8.0$ \\
$2003-2009$ & Spring & $56.7 \pm 38.6$ & $13.4 \pm 3.4$ & $22.8 \pm 1.6$ & $7.9 \pm 6.5$ \\
$1989-1992$ & Autumn & 11.0 & 14.3 & 25.9 & 17.0 \\
$1993-2002$ & Autumn & $46.2 \pm 35.6$ & $15.3 \pm 1.7$ & $24.7 \pm 1.9$ & $31.8 \pm 39.4$ \\
$2003-2009$ & Autumn & $37.5 \pm 35.8$ & $16.9 \pm 1.7$ & $24.3 \pm 1.5$ & $11.8 \pm 11.5$
\end{tabular}



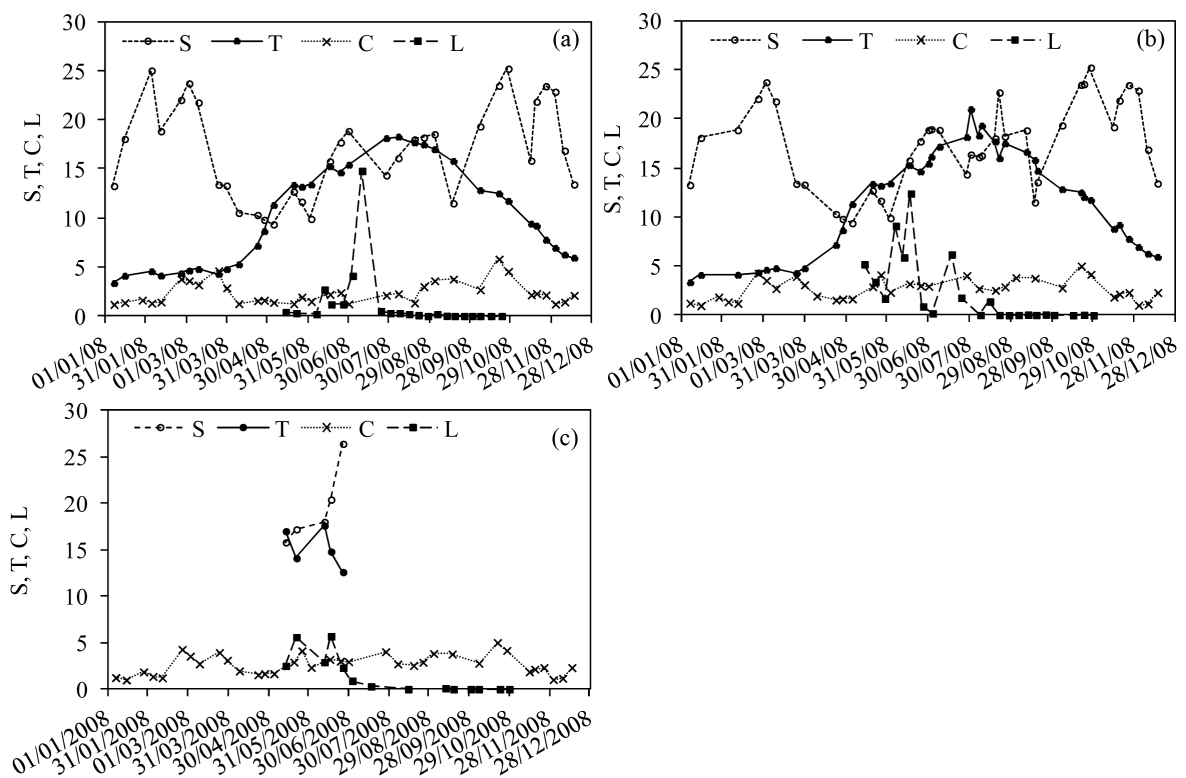

(c)

Figure 6. Mytilus edulis. Salinity (S, psu), temperature $\left(\mathrm{T},{ }^{\circ} \mathrm{C}\right)$, chlorophyll $a\left(\mathrm{C}, \mu \mathrm{g} \cdot 1^{-1}\right)$, and mussel larval density (L, ind. $\mathrm{l}^{-1}$ ) in 2008 in (a) Musholm Bay; (b) Svendborg Sound; (c) Horsens Fjord.

Table 2. Mytlilus edulis. Maximum density of mussel larvae (peak) in Kerteminde Bay along with corresponding temperature, salinity and chlorophyll $a$ measured at the peak date in the years 2008 to 2011.

\begin{tabular}{cccccc}
\hline Year & Date & Max. density $\left(\mathrm{ind} \cdot \mathrm{l}^{-1}\right)$ & Temp. $\left({ }^{\circ} \mathrm{C}\right)$ & Salinity $(\mathrm{psu})$ & $\mathrm{Chla}\left(\mu \mathrm{g} \cdot \mathrm{l}^{-1}\right)$ \\
\hline 2008 & 17-July & 3.4 & 16.8 & 16.6 & 1.7 \\
2009 & 22-June & 4.6 & 14.1 & 20.8 & 0.9 \\
2010 & 16-July & 3.9 & 20.1 & 13.6 & 2.4 \\
2011 & 18-May & 7.9 & 10.9 & 14.2 & 1.6 \\
\hline
\end{tabular}

Table 3. Mytlilus edulis. Maximum density of mussel larvae (peak) on 3 mussel larval sampling locations in 2008 along with corresponding temperature, salinity and chlorophyll $a$ measured at the peak date.

\begin{tabular}{cccccc}
\hline Location & Date & Max. density $\left(\right.$ ind $\left.\cdot l^{-1}\right)$ & Temp. $\left({ }^{\circ} \mathrm{C}\right)$ & Salinity $(\mathrm{psu})$ & Chla $\left(\mu \mathrm{g} \cdot l^{-1}\right)$ \\
\hline Musholm Bay & 10-July & 2.7 & 18.4 & 12.9 & 0.7 \\
Svendborg Sund & 17-June & 12.4 & 15.3 & 15.8 & 3.2 \\
Horsens Fjord & 17-June & 5.7 & 14.8 & 20.4 & 3.2 \\
\hline
\end{tabular}

mussel larvae. After the maximum summer peak, mussel larvae may be found at low densities throughout the season until a less pronounced secondary and shorter autumn peak may appear, as typically seen in Limfjorden (Figure 2 and Figure 3, Table 4), but not in the Great Belt region (Figure 5 and Figure 6). In all cases, the mussel larvae disappear when the autumn temperature has decreased below about $12^{\circ} \mathrm{C}$. This pattern reflects the annual spawning cycle of mussels in temperate waters as described by Dare [3].

The significant decrease in veliger larval density in Limfjorden after 2002 is not obvious. Statistical analysis showed that the annual mean temperatures in Limfjorden (Skive Fjord) did not change significantly in the period 1982 to 2010 (Figure 4), but the decrease in larval density may perhaps be correlated with overfishing (dredging) and reduction of the mussel stock in Limfjorden [12] [14], or a tendency towards more severely reduced oxygen concentrations and mass-killing of mussels during summer [15].

Dolmer \& Stenalt [13] measured the mussel larval densities from April to September 1999 at 2 locations in Limfjorden, namely in the northern central part (Løgstør Bredning) and in Skive Fjord. At both locations the 
H. U. Riisgård et al.

Table 4. Mytlilus edulis. Maximum mussel larval density (L), water temperature (T), salinity (S) and chlorophyll $a$ concentration (C) on collection dates in Skive Fjord in the period 1989 to 2009. s/a = spring/autumn.

\begin{tabular}{|c|c|c|c|c|c|c|}
\hline Year & s/a & Date & Max. L (ind $\cdot l^{-1}$ ) & $\mathrm{T}\left({ }^{\circ} \mathrm{C}\right)$ & S (psu) & $C\left(\mu g \cdot l^{-1}\right)$ \\
\hline \multirow{2}{*}{1989} & s & 10-Jul & 22 & 20.6 & 23.5 & 19 \\
\hline & a & - & - & - & & \\
\hline \multirow{2}{*}{1990} & $\mathrm{~s}$ & 23-May & 8 & 14.2 & 25.3 & 17.0 \\
\hline & $\mathrm{a}$ & - & - & - & & \\
\hline \multirow{2}{*}{1991} & $\mathrm{~s}$ & - & - & - & & \\
\hline & a & - & - & - & & \\
\hline \multirow{2}{*}{1992} & $\mathrm{~s}$ & 1-Jun & 66 & 20.4 & 20.2 & 22.0 \\
\hline & a & 7-Sep & 11 & 14.3 & 25.9 & 17.0 \\
\hline \multirow{2}{*}{1993} & $\mathrm{~s}$ & 4-Jun & 193 & 15.1 & 24.6 & 15.0 \\
\hline & a & 23-Aug & 13 & 15.0 & 27.6 & 2.0 \\
\hline \multirow{2}{*}{1994} & $\mathrm{~s}$ & 16-May & 145 & 15.1 & 21.3 & 34.0 \\
\hline & a & 5-Sep & 19 & 16.1 & 24.9 & 49.0 \\
\hline \multirow{2}{*}{1995} & $\mathrm{~s}$ & 27-Jun & 78 & 20.0 & 21.4 & 27.0 \\
\hline & a & 4-Sep & 7 & 16.1 & 23.7 & 9.0 \\
\hline \multirow{2}{*}{1996} & $\mathrm{~s}$ & 13-May & 787 & 9.3 & 21.7 & 17.0 \\
\hline & a & 9-Sep & 21 & 16.2 & 25.3 & 13.0 \\
\hline \multirow{2}{*}{1997} & $\mathrm{~s}$ & 20-May & 511 & 13.5 & 23.4 & 18.0 \\
\hline & a & 15-Sep & 75 & 14.3 & 26.8 & 130.0 \\
\hline \multirow{2}{*}{1998} & $\mathrm{~s}$ & 11-May & 283 & 12.5 & 24.6 & 17.0 \\
\hline & a & 28-Sep & 77 & 14.3 & 25.5 & 20.0 \\
\hline \multirow{2}{*}{1999} & $\mathrm{~s}$ & 21-Jun & 98 & 15.8 & 23.2 & 22.0 \\
\hline & $\mathrm{a}$ & 11 -Oct & 44 & 12.5 & 23.4 & 14.0 \\
\hline \multirow{2}{*}{2000} & $\mathrm{~s}$ & 10-May & 117 & 18.4 & 20.3 & 11.0 \\
\hline & $\mathrm{a}$ & - & - & - & & \\
\hline \multirow{2}{*}{2001} & $\mathrm{~s}$ & 7-May & 712 & 10.4 & 19.4 & 10.0 \\
\hline & $\mathrm{a}$ & 17-Sep & 48 & 14.3 & 23.2 & 15.0 \\
\hline \multirow{2}{*}{2002} & $\mathrm{~s}$ & 8-Apr & 267 & 7.6 & 20.4 & 8.1 \\
\hline & a & 9-Sep & 112 & 18.5 & 21.6 & 34.0 \\
\hline \multirow{2}{*}{2003} & $\mathrm{~s}$ & 26-May & 53 & 13.1 & 21.3 & 19.0 \\
\hline & $\mathrm{a}$ & 1-Sep & 100 & 16.9 & 22.9 & 34.0 \\
\hline \multirow{2}{*}{2004} & $\mathrm{~s}$ & - & - & - & & \\
\hline & $\mathrm{a}$ & 27-Sep & 26 & 13.6 & 26.2 & 11.0 \\
\hline \multirow{2}{*}{2005} & $\mathrm{~s}$ & 17-May & 18 & 12.0 & 24.2 & 5.9 \\
\hline & $\mathrm{a}$ & 12-Sep & 22 & 16.8 & 25.5 & 5.7 \\
\hline \multirow{2}{*}{2006} & $\mathrm{~s}$ & 22-May & 79 & 12.6 & 23.8 & 7.7 \\
\hline & $\mathrm{a}$ & 25-Sep & 18 & 16.6 & 25.1 & 13.0 \\
\hline \multirow{2}{*}{2007} & $\mathrm{~s}$ & 7-May & 114 & 11.0 & & \\
\hline & $\mathrm{a}$ & 23-Jul & 76 & 17.7 & & \\
\hline \multirow{2}{*}{2008} & $\mathrm{~s}$ & 9-Jun & 65 & 20.2 & 20.9 & 4.8 \\
\hline & $\mathrm{a}$ & 6-Jul & 14 & 20.1 & 23.0 & 3.7 \\
\hline \multirow{2}{*}{2009} & $\mathrm{~s}$ & 6-May & 11 & 11.7 & 23.8 & 2.1 \\
\hline & a & 10-Aug & 6 & 20.5 & 23.1 & 3.5 \\
\hline
\end{tabular}


densities were below 20 larvae $\cdot 1^{-1}$ until mid-April, when the densities begun to increase and subsequently peak in mid-June with 579 larvae. $l^{-1}$ and in May-June with 167 larvae $\cdot l^{-1}$ in Løgstør Bredning and Skive Fjord, respectively. A small secondary peak was observed in Løgstør Bredning in August-September whereas no secondary autumn peak was observed in Skive Fjord. The observations from Skive Fjord are not completely in agreement with the observations for 1999 shown in Figure 2, where a distinct summer peak (with 98 larvae $\cdot{ }^{-1}$, Table 4) and an autumn peak (44 larvae $\cdot l^{-1}$ ) is seen. This underlines the importance of spatial and temporal variations which in Limfjorden are mainly caused by a combination of wind- and density-driven water movements [15].

Larsen et al. [20] investigated the temporal patterns of bivalve larvae in the Isefjord, Denmark, and found that the total concentration of bivalve larvae peaked in late June and early July, with one plankton sample having a much higher concentration than the other samples with a density of 188 ind $\cdot l^{-1}$. A small autumn peak with 7.8 ind $\cdot l^{-1}$ was observed in late August, and between these peaks the density ranged between 1.4 and 6.4 ind $\cdot l^{-1}$. In an earlier study in the Isefjord, Jørgensen [4] followed a cohort of bivalve larvae, mainly (about 90\%) Mytilus edulis, during its residence in the plankton. The initial mean density of $90 \mu \mathrm{m}$ shell length larvae was 3150 ind $\cdot l^{-1}$ in late May, but this very high density must be considered as "an extreme peak situation in boreal neretic waters" [11], and has not been report ever since. The abundance of mussel veliger larvae has also been studied in the embayment of Knebel Vig, Denmark, by Fotel et al. [11] who found that the larval density varied from 1.7 to 40.4 ind $\cdot l^{-1}$ in 1994 and 2.7 to 99.0 ind $\cdot l^{-1}$ in 1995 . These observations along with the present account on mussel larvae in Limfjorden and the Great Belt region show that mussel larvae are omnipresent in the inner Danish waters, although the density may vary conspicuously between areas due to differences in number of spawning mussels and hydrography. A recent study by Larsen et al. [21] showed that even a low density of 2 larvae $l^{-1}$ in the vicinity of a suspended mussel-rope in Great Belt (Kerteminde Bay) resulted in 58 and 291 juvenile mussels $\mathrm{cm}^{-1}$ after 16 and $27 \mathrm{~d}$, respectively. Thus, the larval density in most Danish waters seems to be sufficient for recruitment to many future line-mussel farms.

\section{Acknowledgements}

This work formed part of the MarBioShell project supported by the Danish Agency for Science, Technology and Innovation for the period January 2008 to December 2012. Thanks are due to Sandrine Serre, Coralie BarthJensen, and Caroline Vandt-Madsen for practical assistance, to the Danish Nature Agency, Danish Ministry of the Environment, for providing zooplankton and hydrographical data.

\section{References}

[1] Seed, R. (1976) Ecology. In: Bayne, B.L., Ed., Marine Mussels: Their Ecology and Physiology, Cambridge University Press, Cambridge, 13-65.

[2] Savage, R.E. (1956) The Great Spatfall of Mussels in the River Conway Estuary in Spring 1940. Fisheries Investigations Series II, 20, 1-21.

[3] Dare, P.J. (1976) Settlement, Growth and Production of the Mussel, Mytilus edulis L., in Morecambe Bay, England. Fisheries Investigations Series II, 28, 1-25.

[4] Jørgensen, C.B. (1981) Mortality, Growth, and Grazing Impact of a Cohort of Bivalve Larvae, Mytilus edulis L. Ophelia, 20, 185-192. http://dx.doi.org/10.1080/00785236.1981.10426570

[5] Bayne, B.L. (1965) Growth and the Delay of Metamorphosis of the Larvae of Mytilus edulis. Ophelia, 2, 1-47. http://dx.doi.org/10.1080/00785326.1965.10409596

[6] Riisgård, H.U., Randløv, A. and Kristensen, P.S. (1980) Rates of Water Processing, Oxygen Consumption and Efficiency of Particle Retention in Veligers and Young Post-Metamorphic Mytilus edulis. Ophelia, 19, 37-47. http://dx.doi.org/10.1080/00785326.1980.10425505

[7] Jespersen, H. and Olsen, K. (1982) Bioenergetics in Veliger Larvae of Mytilus edulis L. Ophelia, 21,101-113. http://dx.doi.org/10.1080/00785236.1982.10426580

[8] Sprung, M. (1984) Physiological Energetics of Mussel Larvae (Mytilus edulis). I. Shell Growth and Biomass. Marine Ecology Progress Series, 17, 283-293. http://dx.doi.org/10.3354/meps017283

[9] Gosling, E. (2003) Bivalve Molluscs. Biology, Ecology and Culture. Fishing News Books, Blackwell, 443. http://dx.doi.org/10.1002/9780470995532

[10] Thorson, G. (1961) Length of Pelagic Larval Life in Marine Bottom Invertebrates as Related to Larval Transport by Ocean Currents. In: Sears, M., Ed., Oceanography, American Association for the Advancement of Science, Washing- 
ton DC, 67, 455-474.

[11] Fotel, F.L., Jensen, N.J., Wittrup, L. and Hansen, B.W. (1999) In Situ and Laboratory Growth by a Population of Blue Mussel Larvae (Mytilus edulis L.) from a Danish Embayment, Knebel Vig. Journal of Experimental Marine Biology and Ecology, 233, 213-230. http://dx.doi.org/10.1016/S0022-0981(98)00136-1

[12] Dolmer, P. and Frandsen, R.P. (2002) Evaluation of the Danish Mussel Fishery: Suggestions for an Ecosystem Management Approach. Helgoland Marine Research, 56, 13-20. http://dx.doi.org/10.1007/s10152-001-0095-6

[13] Dolmer, P. and Stenalt, E. (2010) The Impact of the Adult Blue Mussel (Mytilus edulis) Population on Settling of Conspecific Larvae. Aquaculture International, 18, 3-17. http://dx.doi.org/10.1007/s10499-009-9266-2

[14] Dinesen, G.E., Timmermann, K., Roth, E., Markager, S., Ravn-Jonsen, L., Hjorth, M., Holmer, M. and Støttrup, J.G. (2011) Mussel Production and Water Framework Directive Targets in the Limfjord, Denmark: An Integrated Assessment for Use in System-Based Management. Ecology and Society, 16, 26. http://dx.doi.org/10.5751/ES-04259-160426

[15] Riisgård, H.U., Andersen, P. and Hoffmann, E. (2012) From Fish to Jellyfish in the Eutrophicated Limfjorden (Denmark). Estuaries and Coasts, 35, 701-713. http://dx.doi.org/10.1007/s12237-012-9480-4

[16] Petersen, J.K., Hasler, B., Timmermann, K., Nielsen, P., Tørring, D.B., Larsen, M.M. and Holmer, M. (2014) Mussels as a Tool for Mitigation of Nutrients in the Marine Environment. Marine Pollution Bulletin, 82, 137-143. http://dx.doi.org/10.1016/j.marpolbul.2014.03.006

[17] Riisgård, H.U., Lundgreen, K. and Larsen, P.S. (2014) Potential for Production of "Mini-Mussels” in Great Belt (Denmark) Evaluated on Basis of Actual Growth of Young Mussels Mytilus edulis. Aquaculture International, 22, 859-885. http://dx.doi.org/10.1007/s10499-013-9713-y

[18] Riisgård, H.U., Lundgreen, K. and Larsen, P.S. (2012) Field Data and Growth Model for Mussels Mytilus edulis in Danish Waters. Marine Biology Research, 8, 683-700. http://dx.doi.org/10.1080/17451000.2012.678857

[19] Riisgård, H.U., Bøttiger, L. and Pleissner, D. (2012) Effect of Salinity on Growth of Mussels, Mytilus edulis, with Special Reference to Great Belt (Denmark). Open Journal of Marine Science, 2, 167-176. http://dx.doi.org/10.4236/ojms.2012.24020

[20] Larsen, J.B., Frischer, M.E., Ockelmann, K.W., Rasmussen, L.J. and Hansen, B.W. (2007) Temporal Occurrence of Planktotrophic Bivalve Larvae Identified Morphologically and by Single Step Nested Multiplex PCR. Journal of Plankton Research, 29, 423-436. http://dx.doi.org/10.1093/plankt/fbm027

[21] Larsen, P.S., Lundgreen, K. and Riisgård, H.U. (2013) Bioenergetic Model Predictions of Actual Growth and Allometric Transitions during Ontogeny of Juvenile Blue Mussels Mytilus edulis. In: Nowak, J. and Kozlowski, M., Eds., Mussels: Ecology, Life Habits and Control, Nova Science, New York, 101-122. 